\title{
Outward potassium current oscillations in macrophage polykaryons: extracellular calcium entry and calcium-induced calcium release
}

R.M. Saraiva,

M.O. Masuda and G.M. Oliveira-Castro
Instituto de Biofísica Carlos Chagas Filho, Universidade Federal do Rio de Janeiro, Rio de Janeiro, RJ, Brasil

\author{
Correspondence \\ R.M. Saraiva \\ Laboratório de Eletrofisiologia \\ Cardíaca \\ Instituto de Biofísica Carlos \\ Chagas Filho, UFRJ \\ Bloco G, CCS, Ilha do Fundão \\ 21949-900 Rio de Janeiro, RJ \\ Brasil \\ Fax: 55 (021) 212808193 \\ E-mail: mmasuda@ibccf.biof.ufr..br \\ The present address of G.M. Oliveira- \\ Castro is Universidade Estácio de Sá, \\ Rua do Bispo, 71, Reitoria, \\ 20261-061 Rio de Janeiro, RJ, Brasil. \\ Research supported by CNPq, FINEP \\ and FAPERJ.
}

Received March 14, 1997 Accepted August 19, 1997

\begin{abstract}
Outward current oscillations associated with transient membrane hyperpolarizations were induced in murine macrophage polykaryons by membrane depolarization in the absence of external $\mathrm{Na}^{+}$. Oscillations corresponded to a cyclic activation of $\mathrm{Ca}^{2+}$-dependent $\mathrm{K}^{+}$currents $\left(\mathrm{IK}_{\mathrm{Ca}}\right)$ probably correlated with variations in intracellular $\mathrm{Ca}^{2+}$ concentration. Addition of external $\mathrm{Na}^{+}(8 \mathrm{mM})$ immediately abolished the outward current oscillations, suggesting that the absence of the cation is necessary not only for their induction but also for their maintenance. Oscillations were completely blocked by nisoldipine. Ruthenium red and ryanodine reduced the number of outward current cycles in each episode, whereas quercetin prolonged the hyperpolarization 2- to 15-fold. Neither low molecular weight heparin nor the absence of a $\mathrm{Na}^{+}$gradient across the membrane had any influence on oscillations. The evidence suggests that $\mathrm{Ca}^{2+}$ entry through a pathway sensitive to $\mathrm{Ca}^{2+}$ channel blockers is elicited by membrane depolarization in $\mathrm{Na}^{+}$-free medium and is essential to initiate oscillations, which are also dependent on the cyclic release of $\mathrm{Ca}^{2+}$ from intracellular $\mathrm{Ca}^{2+}$-sensitive stores; $\mathrm{Ca}^{2+}$ ATPase acts by reducing intracellular $\mathrm{Ca}^{2+}$, thus allowing slow deactivation of $\mathrm{IK}_{\mathrm{Ca}}$. Evidence is presented that neither a $\mathrm{Na}^{+} / \mathrm{Ca}^{2+}$ antiporter nor $\mathrm{Ca}^{2+}$ release from $\mathrm{IP}_{3}$-sensitive $\mathrm{Ca}^{2+}$ stores participate directly in the mechanism of oscillation.
\end{abstract}

Key words

- Macrophage

- Macrophage polykaryon

- $\mathrm{Ca}^{2+}$-dependent $\mathrm{K}^{+}$current

- Membrane potential oscillations

- Calcium-induced calcium release

- $\mathrm{Ca}^{2+}$ ATPase

\section{Introduction}

Transmembrane potential oscillations have been encountered in many cell types, including both excitable and non-excitable cells. They are often associated with oscillations in intracellular $\mathrm{Ca}^{2+}$ concentrations that activate $\mathrm{Ca}^{2+}$-dependent $\mathrm{K}^{+}$currents $\left(\mathrm{IK}_{\mathrm{Ca}}\right)$ (1-3) and can be useful as an alternative to direct measurement of intracellular $\mathrm{Ca}^{2+}$ concentration $(4,5)$. This correlation has been established by simultaneous recordings of membrane potential and intracellular $\mathrm{Ca}^{2+}$ in fibroblasts (2) and endothelial cells (3). In non-excitable cells, $\mathrm{Ca}^{2+}$ oscillations are generated by different mechanisms: cyclic $\mathrm{Ca}^{2+}$ release from intracellular sources, either by inositol triphosphate $\left(\mathrm{IP}_{3}\right)$ as in Xenopus oo- 
cytes and megakaryocytes (6-8), or by cytoplasmic $\mathrm{Ca}^{2+}$-activated mechanisms as in hamster eggs (9), or $\mathrm{Ca}^{2+}$ entry-dependent oscillations as in endothelial cells (3). These different mechanisms may also interact to modulate $\mathrm{Ca}^{2+}$ oscillations, as is the case for $\mathrm{IP}_{3}{ }^{-}$and $\mathrm{Ca}^{2+}$-sensitive mechanisms in pancreatic acinar cells (10), hepatocytes and endothelial cells (1). The presence of extracellular $\mathrm{Ca}^{2+}$ is also important, since oscillations cannot be sustained when $\mathrm{Ca}^{2+}$ is removed from the extracellular medium. Extracellular $\mathrm{Ca}^{2+}$ allows replenishment of intracellular stores via $\mathrm{Ca}^{2+}$ influx pathways that are not yet fully understood (1). In nonexcitable cells, the oscillation patterns vary widely (1). In a single cell type, the pattern of oscillations can vary depending on the stimulus and on the individual cell. However, the response of the same cell to repeated exposure to the same agonist can be remarkably similar (1).

In macrophages, spontaneous membrane potential oscillations due to a $\mathrm{Ca}^{2+}$-dependent increase in $\mathrm{K}^{+}$conductance have been described (11). Because of their episodic nature, these spontaneous oscillations are virtually inaccessible experimentally. However, qualitatively similar oscillations can be induced reproducibly in macrophage polykaryons when the cells are depolarized in $\mathrm{Na}^{+}$-free medium. These oscillations consist of cyclic hyperpolarizations of membrane potential of progressively decreasing amplitude. Each hyperpolarization lasts 3 to $5 \mathrm{~s}$. Each oscillation event, on average, is composed of 5 cycles. These oscillations have been shown to depend on extracellular $\mathrm{Ca}^{2+}$, and the underlying mechanism is a cyclic opening of $\mathrm{Ca}^{2+}$-dependent $\mathrm{K}^{+}$channels (12). Thus, these oscillations may serve as a model for studying the mechanisms underlying spontaneous oscillations.

However, there is no agreement with respect to the role of $\mathrm{Ca}^{2+}$ oscillations or the physiological relevance of electrical activity in macrophages. While $\mathrm{Ca}^{2+}$ is a known sec- ond messenger, it is not clear how oscillatory changes in internal $\mathrm{Ca}^{2+}$ would have an advantage over step changes (4). Thus, there are few well-established links between $\mathrm{Ca}^{2+}$ oscillations and cellular responses. A role for $\mathrm{Ca}^{2+}$ oscillations has been proposed for fluid secretion in pancreatic acinar cells (13) and in neutrophil migration (14) and in terms of allowing replenishment of intracellular calcium stores (4). Calcium oscillations are also detected during frustrated phagocytosis and adherence in macrophages (15). Nonetheless, the fact that an oscillatory signal can vary in amplitude and frequency, as well as in position (calcium waves (16)), suggests that $\mathrm{Ca}^{2+}$ oscillations have an unusual potential for encoding cellular functions $(1,4,16)$.

There are also indications of a link between electrical activity and macrophage functions: ionic currents are activated by the Fc fraction of immunoglobulin (17) and by extracellular ATP (18-20); oscillations of potassium currents are induced in mouse peritoneal macrophages by C5a (21) and activation of a $\mathrm{Ca}^{2+}$-dependent, non-selective current is associated with superoxide release subsequent to phagocytosis (22).

In the present study, we examined the genesis and modulation of the depolarization-induced outward $\mathrm{K}^{+}$current oscillations in macrophage polykaryons and evaluated the role of the various mechanisms involved in intracellular $\mathrm{Ca}^{2+}$ homeostasis, including calcium channels, $\mathrm{Na}^{+} / \mathrm{Ca}^{2+}$ antiporter, $\mathrm{Ca}^{2+}$ ATPase and intracellular $\mathrm{Ca}^{2+}$ stores. Knowledge of these mechanisms can help elucidate the physiological role of electrical activity and $\mathrm{Ca}^{2+}$ oscillations in macrophages.

\section{Material and Methods}

\section{Cells}

Murine peritoneal macrophage polykaryons were obtained as previously described (23). Briefly, a glass coverslip was implanted into the mouse peritoneal cavity. After 7 to 
15 days, coverslips were removed from the animal and washed in RPMI-1640 (Gibco, Grand Island, NY) buffered with $6 \mathrm{mM}$ HEPES, $\mathrm{pH} 7.3$, and containing 5\% fetal calf serum, penicillin $(100 \mathrm{U} / \mathrm{ml})$ and streptomycin $(100 \mu \mathrm{g} / \mathrm{ml})$ at $37^{\circ} \mathrm{C}$. Coverslips were transferred to a 5-ml culture chamber on the stage of a phase-contrast Leitz microscope equipped with a Heineke condenser and a UMK 50/0.60 objective. The large macrophage polykaryons were easily identified on the surface of the coverslips.

\section{Solutions}

Unless otherwise stated, experiments were performed in standard extracellular saline containing $5 \mathrm{mMKCl}, 2 \mathrm{mMCaCl}_{2}, 1 \mathrm{mM} \mathrm{MgCl}_{2}$, $6 \mathrm{mM}$ HEPES and $140 \mathrm{mM}$ Tris-HCl, $\mathrm{pH}$ 7.3. In whole-cell patch-clamp recordings the internal solution contained $140 \mathrm{mM} \mathrm{KCl}, 5 \mathrm{mM}$ $\mathrm{NaCl}, 0.2 \mathrm{mM} \mathrm{CaCl}_{2}, 2 \mathrm{mM} \mathrm{MgCl}{ }_{2}, 10 \mathrm{mM}$ HEPES-KOH, $0.6 \mathrm{mM} \mathrm{K}_{2}$ EGTA, pH 7.2, and pCa 7.04 (calculated according to Fabiato and Fabiato (24)). When sodium concentration was increased (both in the external and internal saline) osmolarity was corrected by decreasing the major cation Tris in the external saline and potassium in the internal saline. No osmolarity correction was made for the sodium-free internal saline.

\section{Reagents}

Nisoldipine (Bayer, Munich, Germany) and ryanodine ( $\mathrm{K} \& \mathrm{~K}$ Laboratories, California) were dissolved in dimethyl sulfoxide (DMSO), quercetin (Sigma, St. Louis, MO) was dissolved in absolute ethanol, low molecular weight heparin (Sigma) was dissolved in internal saline, and ruthenium red (British Drug Houses, Poole, England) in water.

\section{Electrophysiological technique}

Experiments were carried out at room temperature $\left(23-28^{\circ} \mathrm{C}\right)$. Whole-cell patch- clamping was performed using an EPC-7 amplifier (List Electronic, Darmstadt, Germany) according to standard procedures (25). A giga-ohm seal was formed using a heatpolished micropipette back-filled with the internal saline solution. Standard electrophysiological recordings were performed using glass microelectrodes ( 30 to $60 \mathrm{M} \Omega$ tip resistance). The electrodes were back-filled with a $2.5 \mathrm{M} \mathrm{KCl}$ solution and connected to a high-input-impedance preamplifier with an active bridge circuit (M4A Electromer, WP Instruments, New Haven, CT) allowing simultaneous recording of the transmembrane potential and of the injected currents.

Iontophoretic intracellular calcium injections were performed through a second glass microelectrode back-filled with $0.5 \mathrm{MCaCl}_{2}$, as previously described (23).

The statistical tests used are specified together with the corresponding data in the Results section. In all cases differences were considered to be significant when $\mathrm{P}<0.05$.

\section{Results}

\section{Membrane potential oscillations and sodium dependence}

Oscillations of membrane potential and current were obtained reproducibly when macrophages were depolarized in the absence of external $\mathrm{Na}^{+}$(Figure 1). Both responses were similar in periodicity, number and duration of cycles and progressive amplitude decrease. The most common pattern has been described (12) and is shown in Figure 1. However, there were variations in frequency and in shape (progressive amplitude increase or no change in amplitude of the successive cycles during an oscillatory episode). Oscillation was observed in 58\% of the cells $(\mathrm{N}=325)$. Both current and voltage oscillations were immediately interrupted when the depolarization pulse was turned off and a similar pattern was elicited by a new depolarization (data not shown). 
Figure 1 - Voltage and current oscillations induced by depolarization in $\mathrm{Na}^{+}$-free medium. $A$, Depolarization by constant outward current injection induced membrane potential oscillations in macrophage polykaryons bathed in $\mathrm{Na}^{+}$-free saline solution. Resting membrane potential $=-48 \mathrm{mV}$. B, Outward current oscillation elicited when the transmembrane poHolding potential $=-50 \mathrm{mV}$. Note that current and voltage oscillations have similar patterns. Records were obtained by means of whole-cell patchclamp under current clamp (A) and voltage clamp (B) conditions in two different cells. Calibration bars in all figures were positioned in such a way that the current and voltage values presented correspond to actual values in the tracings. tential is clamped at $+40 \mathrm{mV}$.

The presence of $8 \mathrm{mM} \mathrm{NaCl}$ in the external saline was sufficient to prevent membrane potential oscillations $(\mathrm{N}=8)$. Addition of $\mathrm{Na}^{+}$to the external medium during an oscillation abolished both hyperpolarizing voltage (Figure 2A) and outward current
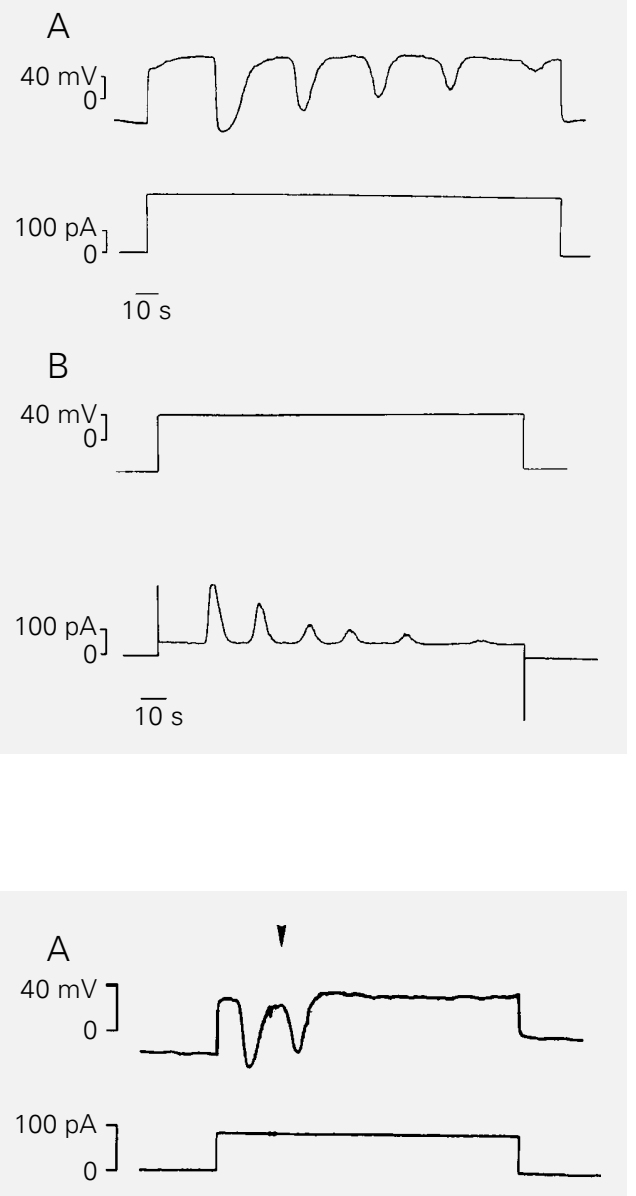

Figure 2 - Effect of external $\mathrm{Na}^{+}$. Both voltage (A) and current (B) oscillations were interrupted by the addition of $\mathrm{NaCl}$ to the external medium to a final concentration of $8 \mathrm{mM}$ (arrowheads). Intracellular saline was $\mathrm{Na}^{+}$free in both cases. Note that oscillation retains its characteristic pattern until the addition of $\mathrm{NaCl}$. Whole-cell patch-clamp under current clamp conditions (A), with a resting membrane potential $=$ $-20 \mathrm{mV}$, and under voltage clamp conditions (B), with a holding potential $=-40 \mathrm{mV}$. oscillations (Figure 2B) in $88 \%$ of the cells tested $(\mathrm{N}=8)$.

Participation of the $\mathrm{Na}^{+} / \mathrm{Ca}^{2+}$ antiporter in the $\mathrm{Ca}^{2+}$ influx may explain the dependence on the absence of external $\mathrm{Na}^{+}$(26). The inverted $\mathrm{Na}^{+}$gradient could result in reversal of this antiporter, leading to $\mathrm{Ca}^{2+}$ influx. This hypothesis was tested using $\mathrm{Na}^{+}-$ free internal saline to eliminate any $\mathrm{Na}^{+}$ gradient across the membrane. An increase in the amplitude of the resting membrane potential was observed under these experimental conditions (Table 1). However, the same percentage of cells exhibited depolarization-induced oscillations with characteristics similar to those observed for cells maintained under control conditions (Figure 2 and Table 1). An increase in the internal $\mathrm{Na}^{+}$ concentration to $15 \mathrm{mM}$ did not significantly change resting potential or the pattern of the oscillatory response (Table 1).

\section{Extracellular calcium}

The possible participation of an L-type $\mathrm{Ca}^{2+}$ channel in the genesis of the oscillations was investigated. Nisoldipine, a blocker specific for L-type $\mathrm{Ca}^{2+}$ channels (27), completely blocked the oscillations when added to the external medium $(\mathrm{N}=6)$ (Figure 3C). This effect persisted even when the depolarizing pulse amplitude was increased and was reversed by washing out the nisoldipine (data not shown). Addition of the solvent (DMSO) did not affect membrane potential oscillation (data not shown). The calcium-activated potassium efflux in human erythrocytes (28) and $\mathrm{N}$-type potassium channels $\left(\mathrm{K}_{\mathrm{n}}\right.$ channels) in human and murine $\mathrm{T}$ lymphocytes $(29,30)$ is blocked by dihydropyridine and other $\mathrm{Ca}^{2+}$ channel blockers. In order to test whether nisoldipine acts by blocking $\mathrm{IK}_{\mathrm{Ca}}$, calcium was injected iontophoretically before (Figure 3B) and after (Figure 3D) the addition of the blocking agent. Calcium injection induced hyperpolarization in both situations. 


\section{Calcium ATPase}

Quercetin is a flavone of plant origin that blocks $\mathrm{Ca}^{2+}$ ATPase in plasma membranes as well as in sarcoplasmic reticulum $(31,32)$. Figure 4 illustrates one experiment where quercetin, added to the external medium after membrane potential oscillation had been induced, generated a long-lasting hyperpolarization ( $30 \mathrm{~s})$. An increase in duration of hyperpolarization ranging from 2 - to 15 -fold was seen in $48 \%$ of the cells tested $(\mathrm{N}=21)$. Hyperpolarizing cycles lasted $9.5 \pm 5.0 \mathrm{~s}$ (mean $\pm \mathrm{SD} ; \mathrm{N}=21$ ) before quercetin addition and increased to $25.2 \pm 28.9 \mathrm{~s}$ in the presence of quercetin (paired $t$-test after logtransformation, $\mathrm{P}<0.05$ ). A single, long-lasting hyperpolarization similar to that shown in Figure 4 was observed in $60 \%$ of the cells that responded to quercetin addition. Quercetin seems to prolong the time during which intracellular $\mathrm{Ca}^{2+}$ concentration is high enough to activate $\mathrm{IK}_{\mathrm{Ca}}$, thus maintaining a hyperpolarized membrane potential.

\section{Intracellular calcium stores}

There are two mechanisms of $\mathrm{Ca}^{2+}$ release from the endoplasmic reticulum, one sensitive to $\mathrm{IP}_{3}$ and the other to $\mathrm{Ca}^{2+}$ itself (33). Both mechanisms were tested using specific inhibitors.

Low molecular weight heparin $(200 \mu \mathrm{g} /$ $\mathrm{ml}$ ), which blocks $\mathrm{Ca}^{2+}$ release from $\mathrm{IP}_{3-}$ sensitive intracellular $\mathrm{Ca}^{2+}$ stores (33), did not significantly alter the membrane potential, the percentage of cells responding to depolarization or the characteristics of the membrane potential oscillations (Table 2).

The possible involvement of $\mathrm{Ca}^{2+}$-induced $\mathrm{Ca}^{2+}$ release was tested by using ruthenium red in the patch-clamp pipette, or ryanodine in the external medium $(6,33)$. A comparison of cells from the same population indicated a striking decrease in the number of hyperpolarizing cycles in the presence of ruthenium red (50 $\mu \mathrm{M}$, Table 2$)$. Ryanodine
Table 1 - Effect of internal sodium on membrane potential and oscillations.

Data are reported as mean \pm SD or median [min, max] for the number of cases given in parentheses. ${ }^{*} \mathrm{P}<0.05$ between the two groups (ANOVA). No statistically significant differences in the number of cycles were observed among groups (Kruskal-Wallis test).

\begin{tabular}{lcl}
\hline Internal sodium $(\mathrm{mM})$ & Membrane potential $(\mathrm{mV})$ & Number of cycles \\
\hline 0 & $-62.1 \pm 17.6(13)^{*}$ & $4[1,7](5)$ \\
5 & $-38.6 \pm 20.6(19)^{*}$ & $3.5[2,10](24)$ \\
15 & $-30.5 \pm 22.4(8)$ & $2[2,3](3)$
\end{tabular}

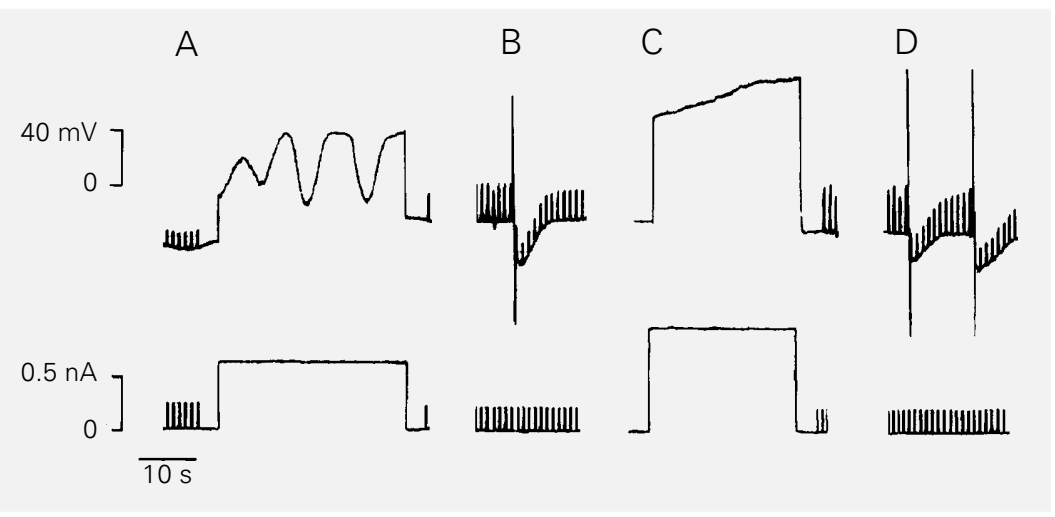

Figure 3 - Inhibition of membrane potential oscillation by nisoldipine. Control situation: depolarization-induced membrane potential oscillation (A) and hyperpolarization induced by iontophoretic intracellular calcium injection (B). Transmembrane potential oscillation was blocked by nisoldipine $(20 \mu \mathrm{M})$ in extracellular saline $(C)$. Hyperpolarizations induced by iontophoretic intracellular calcium injection were not blocked by nisoldipine (D). Records (AD) were obtained from a single cell using standard intracellular microelectrodes. In $B$ and $D$, iontophoretic injections of calcium were performed through a second microelectrode containing $\mathrm{CaCl}_{2}$. Current pulses of $0.20 \mathrm{nA}$ were injected in order to monitor membrane resistance. Resting membrane potential $=-20 \mathrm{mV}$.

Table 2 - Effect of intracellular calcium release blockers on oscillations.

Data are reported as median [min, max] for the number of cells given in parentheses. ${ }^{*} \mathrm{P}<0.05$ (Mann-Whitney test); $+P<0.05$ (Wilcoxon test; data from the same cells before (control) and during ryanodine treatment (experimental)).

\begin{tabular}{lll}
\hline & \multicolumn{2}{c}{ Number of cycles } \\
\cline { 2 - 3 } & \multicolumn{1}{c}{ Control } & Experimental \\
\hline Ruthenium red $(50 \mu \mathrm{M})$ & $3[0,7](13)$ & $1[0,3](17)^{*}$ \\
Heparin $(200 \mu \mathrm{g} / \mathrm{ml})$ & $3[0,7](13)$ & $3[1,13](8)$ \\
Ryanodine $(1 \mu \mathrm{M})$ & $3[2,4](9)$ & $0[0,1](9)^{+}$
\end{tabular}


Figure 4 - Effect of quercetin on membrane potential oscillation. Quercetin $(0.1 \mathrm{mM})$ applied during the oscillation (arrowhead) prolonged the subsequent hyperpolarizing cycle to almost three times the control value. The record was obtained using a standard electrophysiologic recording technique. Resting membrane potential $=-20 \mathrm{mV}$.

Figure 5 - Effect of ryanodine on membrane potential and outward current oscillations. The number of hyperpolarizing cycles of transmembrane potential (A) and outward current (B) oscillations was reduced by the addition of ryanodine $(1 \mu \mathrm{M})$ to the extracellular saline. Records were obtained using a whole-cell patch-clamp under current clamp (A) and voltage clamp conditions (B). Resting membrane potential $=-12 \mathrm{mV}$. Holding potential $=$ $-40 \mathrm{mV}(\mathrm{B})$.
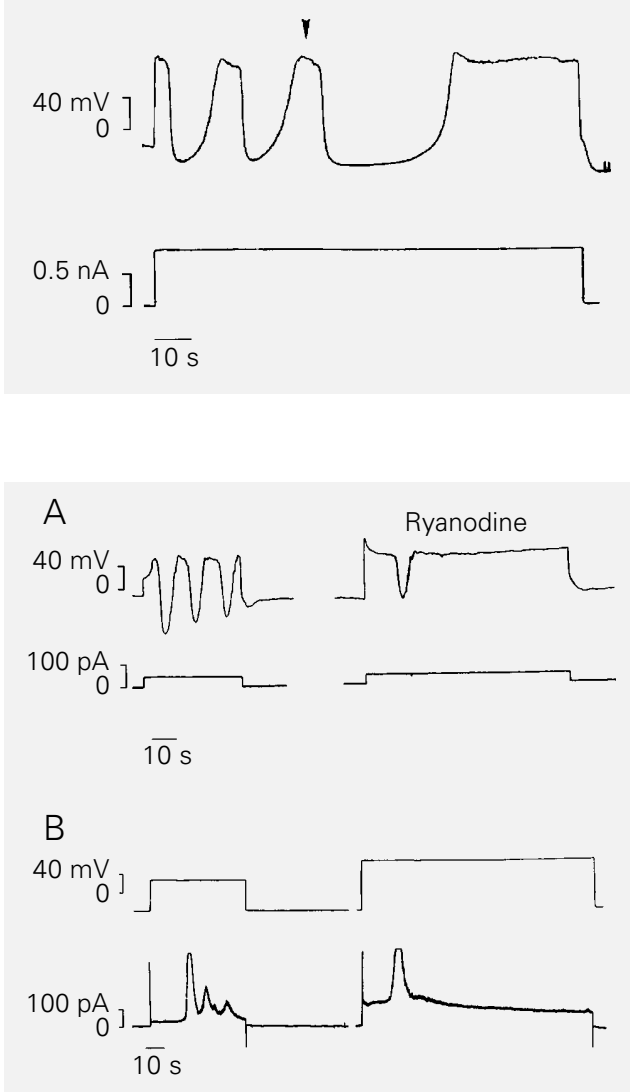

$(1 \mu \mathrm{M})$ also induced a significant decrease in the number of oscillations in the same cell (Figure 5, Table 2). Ryanodine opens the $\mathrm{Ca}^{2+}$-sensitive $\mathrm{Ca}^{2+}$ channel of the internal stores at low concentrations (nanomolar) but blocks them at the concentration used here (micromolar) (6). The results obtained with heparin, ruthenium red and ryanodine indicate that oscillations depend on the release of intracellular $\mathrm{Ca}^{2+}$ from $\mathrm{Ca}^{2+}$-sensitive stores but not from $\mathrm{IP}_{3}$-sensitive stores.

\section{Discussion}

In the present study, we investigated the participation of various processes related to cytoplasmic $\mathrm{Ca}^{2+}$ homeostasis in the regulation of the outward potassium current oscillations activated by depolarization in $\mathrm{Na}^{+}-$ free saline. Our working hypothesis proposes that the cyclic activation of the $\mathrm{IK}_{\mathrm{Ca}}$ would depend on cyclic increases in cyto- plasmic free $\mathrm{Ca}^{2+}$ activity produced by an influx through the plasma membrane, by release from intracellular stores, or by both events.

Here, we showed that nisoldipine, an Ltype $\mathrm{Ca}^{2+}$ channel blocker, abolished membrane potential oscillations and that this effect was not due to the direct inhibition of $\mathrm{IK}_{\mathrm{Ca}}$ by nisoldipine $(28,30)$, since intracellular $\mathrm{Ca}^{2+}$ injection restored membrane hyperpolarization in the presence of the drug (Figure 3D). Other evidence for the participation of $\mathrm{Ca}^{2+}$ influx in the genesis of these membrane potential oscillations has been presented previously, and includes their dependence on extracellular $\mathrm{Ca}^{2+}$ and blockade by D-600 (an L-type $\mathrm{Ca}^{2+}$ channel blocker) (12).

These findings suggest that $\mathrm{Ca}^{2+}$ influx through a dihydropyridine-sensitive, depolarization-activated pathway is essential for the oscillations. However, a voltage-dependent $\mathrm{Ca}^{2+}$ channel, such as the L-type $\mathrm{Ca}^{2+}$ channel, has not yet been found in the macrophage membrane $(29,34)$ or in the majority of non-excitable cells (1). Calcium influx pathways in non-excitable cells include channels activated by second messengers such as $\mathrm{Ca}^{2+}$, inositol 1,3,4,5-tetrakisphosphate ( $\left.\mathrm{IP}_{4}\right)$ (16) and $\mathrm{IP}_{3}(29)$, channels activated by depletion of intracellular $\mathrm{Ca}^{2+}$ stores (1), and non-selective cation channels (35). In macrophages, a $\mathrm{Ca}^{2+}$-selective current activated by depletion of intracellular $\mathrm{Ca}^{2+}$ stores (36) and an ATP-activated $\mathrm{Ca}^{2+}$ channel (18) have been described. Voltage-sensitive, non-selective cation channels (37) and another ATPactivated cation channel (19) are also present. Thus, one possible pathway for $\mathrm{Ca}^{2+}$ influx in macrophage polykaryons would be a voltage-dependent cation channel which, in a $\mathrm{Na}^{+}$-free environment, allows $\mathrm{Ca}^{2+}$ permeation. An analogous situation has been reported for the potassium channel in guard cell membranes of Vicia faba, where $\mathrm{Ca}^{2+}$ enters the cell in the absence of potassium (38). However, the fact that we did not detect 
an inward current associated with depolarization is puzzling. Either this current is too small to be detected under our experimental conditions or some outward current is activated simultaneously.

The reversal of the $\mathrm{Na}^{+} / \mathrm{Ca}^{2+}$ antiporter was another possible $\mathrm{Ca}^{2+}$ influx pathway studied. Reversal of this antiporter in the absence of extracellular $\mathrm{Na}^{+}$has been demonstrated in aortic smooth muscle cells (26). However, the use of $\mathrm{Na}^{+}$-free internal solution in the patch-clamp experiments in order to minimize the $\mathrm{Na}^{+}$gradient had no influence on the induction of oscillations by depolarization (Figure 2). Nevertheless, indirect participation of this exchanger cannot be ruled out, since reversal or blockade would raise the background cytoplasmic $\mathrm{Ca}^{2+}$ concentration.

When macrophage polykaryons were exposed to the sodium-free saline pipette in patch-clamp experiments, a significant increase in the resting membrane potential was observed. This increase cannot be attributed to the expected decrease in the electrochemical sodium gradient or to the inhibition of the sodium potassium pump activity since both conditions would depolarize the cell. One possibility is that the decrease in internal sodium would somehow increase resting potassium conductance and thus the resting potential. Actually, a blocking effect of intracellular sodium on a calcium-dependent potassium current has been reported in bovine adrenal chromaffin cells (39).

The intracellular $\mathrm{Ca}^{2+}$ stores may participate in the genesis of oscillations through $\mathrm{Ca}^{2+}$ - and/or $\mathrm{IP}_{3}$-sensitive mechanisms, both known to be functional in macrophages (40). Ruthenium red and ryanodine, which block $\mathrm{Ca}^{2+}$-induced $\mathrm{Ca}^{2+}$ release at the concentrations used $(6,33)$, significantly decreased the number of oscillation cycles in macrophage polykaryons, thus indicating the participation of this mechanism in the genesis of the oscillations. This observation reinforces the importance of $\mathrm{Ca}^{2+}$ influx for increasing cy- toplasmic $\mathrm{Ca}^{2+}$ and triggering $\mathrm{Ca}^{2+}$ release from this store. On the other hand, low molecular weight heparin, a blocker of $\mathrm{IP}_{3}-$ induced $\mathrm{Ca}^{2+}$ release (16), did not have a significant effect on the oscillations, excluding the participation of this $\mathrm{Ca}^{2+}$ pool in its genesis.

The prolongation of the duration of the hyperpolarization of the first oscillation cycle following quercetin addition (Figure 4) suggests that each hyperpolarizing cycle is terminated normally by a decrease in cytoplasmic free $\mathrm{Ca}^{2+}$. Such a decrease, mediated by $\mathrm{Ca}^{2+}$ ATPase activity, would deactivate $\mathrm{IK}_{\mathrm{Ca}}$ and allow membrane potential repolarization.

The fact that the amplitudes of the hyperpolarizing cycles usually decrease progressively and finally subside after a mean of 5 cycles may be the result of several factors, including voltage-dependent inactivation of the $\mathrm{Ca}^{2+}$ influx pathway, depletion of intracellular $\mathrm{Ca}^{2+}$ stores, inactivation of $\mathrm{IK}_{\mathrm{Ca}}$, or desensitization of the intracellular $\mathrm{Ca}^{2+}$-release mechanism. At present, we do not know which of these processes contribute to the termination of the oscillations. The fact that new oscillations can be induced by a further increase in depolarization (data not shown) rules out a voltage-dependent inactivation of the $\mathrm{Ca}^{2+}$ influx pathway and of $\mathrm{IK}_{\mathrm{Ca}}$. Inactivation of $\mathrm{IK}_{\mathrm{Ca}}$ is also unlikely because intracellular calcium injection restored one hyperpolarization cycle (data not shown). Considering that intracellular $\mathrm{Ca}^{2+}$ stores are only partially repleted after each hyperpolarizing cycle, it is conceivable that a sustained depolarization leads to a progressive decrease in the $\mathrm{Ca}^{2+}$ content of those stores, with the end of oscillations coinciding with their depletion.

Thus, we propose the following hypothesis for the genesis of the depolarizationinduced membrane potential oscillations in macrophage polykaryons in $\mathrm{Na}^{+}$-free medium. Upon depolarization, $\mathrm{Ca}^{2+}$ enters the cell through a dihydropyridine-sensitive path- 
way. The resulting increase in cytoplasmic $\mathrm{Ca}^{2+}$ activity induces the release of $\mathrm{Ca}^{2+}$ from $\mathrm{Ca}^{2+}$-sensitive intracellular stores. This increase in $\mathrm{Ca}^{2+}$ activates $\mathrm{IK}_{\mathrm{Ca}}$ which hyperpolarizes the cell membrane. The $\mathrm{Ca}^{2+}$ ATPase pumps $\mathrm{Ca}^{2+}$ out of the cell and/or into intracellular stores, decreasing cytoplasmic $\mathrm{Ca}^{2+}$ and deactivating $\mathrm{IK}_{\mathrm{Ca}}$. Additionally, the $\mathrm{Ca}^{2+}$-sensitive intracellular stores are modulated by cytoplasmic calcium itself (41): above a certain intracellular calcium concentration, the open state probability of the calcium-sensitive calcium channels is reduced (42), further decreasing calcium release and consequently $\mathrm{IK}_{\mathrm{Ca}}$, allowing the membrane potential to return to its previous level. If the depolarizing pulse is sustained, intracellular $\mathrm{Ca}^{2+}$ may rise again, so that new cycles occur until one or more of the mechanisms discussed above terminates the oscillation.

The present study demonstrates that the depolarization-induced oscillation of membrane potential in macrophage polykaryons depends on events occurring at both the plasma membrane and the endoplasmic reticulum levels. In addition, we propose that a similar mechanism may account for the spontaneous oscillations that occur in macrophages and macrophage polykaryons. The reproducible oscillatory phenomena presented here can be very useful as a model for the study of the mechanisms for generation of oscillations and their role in cell responses, including those of macrophages.

\section{Acknowledgments}

We are grateful to Drs. Pedro Muanis Persechini, Luiz Anastácio Alves, Cristóvão de Albuquerque and Martha Sorenson for helpful discussions and a critical review of the manuscript, and to Dr. Doris Rosenthal for help with the statistical analysis.

\section{References}

1. Fewtrell C (1993). $\mathrm{Ca}^{2+}$ oscillations in nonexcitable cells. Annual Review of Physiology, 55: 427-454.

2. Ueda S, Oiki S \& Okada Y (1986). Oscillations of cytoplasmic concentrations of $\mathrm{Ca}^{2+}$ and $\mathrm{K}^{+}$in fused $\mathrm{L}$ cells. Journal of Membrane Biology, 91: 65-72.

3. Laskey RE, Adams DJ, Cannel M \& van Breemen C (1992). Calcium entry-dependent oscillations of cytoplasmic calcium concentration in cultured endothelial cell monolayers. Proceedings of the National Academy of Sciences, USA, 89: 16901694.

4. Hille B, Tse A, Tse FW \& Almers W (1994). Calcium oscillations and exocytosis in pituitary gonadotropes. Annals of the New York Academy of Sciences, 710: 261-270.

5. Nathanson MH (1994). Cellular and subcellular calcium signaling in gastrointestinal epithelium. Gastroenterology, 106: 1349-1364.

6. Berridge MJ (1993). Inositol triphosphate and calcium signaling. Nature, 361: 315325.
7. DeLisle S, Krause K, Demming G, Potter BVL \& Welsh MJ (1990). Effect of inositol triphosphate and calcium on oscillation elevations of intracellular calcium in Xenopus oocytes. Journal of Biological Chemistry, 265: 11726-11730.

8. Uneyama C, Uneyama H, Takashi M \& Akaike N (1993). Cytoplasmic pH regulates ATP-induced $\mathrm{Ca}^{2+}$-dependent $\mathrm{K}^{+}$ current in rat megakaryocytes. Biochemical Journal, 295: 317-320.

9. Berridge MJ \& Galione A (1988). Cytosolic calcium oscillators. FASEB Journal, 2: 3074-3082.

10. Wakui $\mathrm{M}$, Osipchuk $\mathrm{YV}$ \& Petersen $\mathrm{OH}$ (1990). Receptor-activated cytoplasmic $\mathrm{Ca}^{2+}$ spiking mediated by inositol triphosphate is due to $\mathrm{Ca}^{2+}$-induced $\mathrm{Ca}^{2+}$ release. Cell, 63: 1025-1032.

11. Oliveira-Castro GM (1983). $\mathrm{Ca}^{2+}$-sensitive $\mathrm{K}^{+}$channels in phagocytic cell membranes. Cell Calcium, 4: 475-492.

12. Soldati L \& Persechini PM (1988). Depolarization of macrophage polykaryons in the absence of external sodium induces a cyclic stimulation of a calcium-activated potassium conductance. Biochimica et Biophysica Acta, 972: 283-292.
13. Kasai H \& Augustine GJ (1990). Cytosolic $\mathrm{Ca}^{2+}$ gradients triggering unidirectional fluid secretion from exocrine pancreas. Nature, 348: 735-738.

14. Marks PW \& Maxfield FR (1990). Transient increases in cytosolic free calcium appear to be required for the migration of adherent human neutrophils. Journal of Cell Biology, 110: 43-52.

15. Kruskal BA \& Maxfield FR (1987). Cytosolic-free calcium increases before and oscillates during frustrated phagocytosis in macrophages. Journal of Cell Biology, 105: 2685-2693.

16. Amundson J \& Clapham D (1993). Calcium waves. Current Opinion in Neurobiology, 3: 375-382.

17. Young JDE, Unkeless JC, Young TM, Mauro A \& Cohn ZA (1983). Role for mouse macrophage $\mathrm{IgG}$ Fc receptor as ligand-dependent ion channel. Nature, 306: 186-189.

18. Naumov AP, Kaznacheyeva EV, Kiselyov KI, Kuryshev YA, Mamin AG \& Mozhayeva GN (1995). ATP-activated inward current and calcium-permeable channels in rat macrophage plasma membranes. Journal of Physiology, 486: 323-337. 
19. Albuquerque C, Oliveira SMC, CoutinhoSilva R, Oliveira-Castro GM \& Persechini PM (1993). ATP- and UTP-induced currents in macrophages and macrophage polykaryons. American Journal of Physiology, 265: C1663-C1673.

20. Hara N, Ichinose M, Sawada M, Imai K \& Maeno T (1990). Activation of single $\mathrm{Ca}^{2+}$ dependent $\mathrm{K}^{+}$channel by external ATP in mouse macrophages. FEBS Letters, 267: 281-284.

21. Ichinose M, Hara N, Sawada M \& Maeno $\mathrm{T}$ (1992). Induction of two $\mathrm{K}^{+}$currents by complement component $\mathrm{C} 5 \mathrm{a}$ in mouse macrophages. Biochimica et Biophysica Acta, 1111: 165-170.

22. Holevinsky KO \& Nelson DJ (1995). Simultaneous detection of free radical release and membrane current during phagocytosis. Journal of Biological Chemistry, 270: 8328-8336.

23. Persechini PM, Araujo EG \& OliveiraCastro GM (1981). Electrophysiology of phagocytic membranes: induction of slow membrane hyperpolarizations in macrophages and macrophage polykaryons by intracellular calcium injection. Journal of Membrane Biology, 61: 81-90.

24. Fabiato A \& Fabiato $F$ (1979). Calculator programs for computing the composition of the solutions containing multiple metals and ligands used for experiments in skinned muscle cell. Journal de Physiologie, 75: 463-505.

25. Hamil OP, Marty E, Neher B, Sackmann B \& Sigworth FJ (1981). Improved patchclamp techniques for high-resolution current recording from cells and cell-free membrane patches. Pflügers Archives. European Journal of Physiology, 391: 85100.
26. Smith JB, Zheng $T$ \& Smith L (1989). Relationship between cytosolic free $\mathrm{Ca}^{2+}$ and $\mathrm{Na}^{+}-\mathrm{Ca}^{2+}$ exchange in aortic muscle cells. American Journal of Physiology, 256 (Cell Physiology, 25): C147-C154.

27. Fleckenstein A (1985). Calcium antagonists and calcium agonists: fundamental criteria and classification. In: Fleckenstein A, van Breemen C, Gro $\beta$ R \& Hoffmeister F (Editors), Cardiovascular Effects of Dihydropyridine-type Calcium Antagonist and Agonists. Springer-Verlag, Berlin, Heidelberg.

28. Kaji DM (1990). Nifedipine inhibits calcium-activated $\mathrm{K}$ transport in human erythrocytes. American Journal of Physiology, 259: C332-C339.

29. Gallin EK (1991). Ion channels in leukocytes. Physiological Reviews, 71: 775811.

30. Randriamampita C, Bismuth G, Debre P \& Trautmann A (1991). Nitrendipine-induced inhibition of calcium influx in a human Tcell clone: role of cell depolarization. Cell Calcium, 12: 313-323.

31. Fewtrell CMS \& Gompters BD (1977). Effect of flavone inhibitors of transport ATPases on histamine secretion from rat mast cells. Nature, 265: 635-636.

32. Shoshan V \& MacLennan DH (1981). Quercetin interaction with the $\left(\mathrm{Ca}^{2+}\right.$ $\left.+\mathrm{Mg}^{2+}\right)$-ATPase of sarcoplasmic reticulum. Journal of Biological Chemistry, 256: 887-892.

33. Petersen $\mathrm{OH} \&$ Wakui M (1990). Oscillating intracellular $\mathrm{Ca}^{2+}$ signals evoked by activation of receptors linked to inositol lipid hydrolysis: mechanism of generation. Journal of Membrane Biology, 118: 93105.
34. Randriamampita C \& Trautmann A (1987). Ionic channels in murine macrophages. Journal of Cell Biology, 105: 761-769.

35. Von Tscharner V, Prod'hom B, Baggiolini $M$ \& Reuter H (1986). Ion channels in human neutrophils activated by a rise in free cytosolic calcium concentration. $\mathrm{Na}$ ture, 324: 369-372.

36. Malayev A \& Nelson DJ (1995). Extracellular $\mathrm{pH}$ modulates the $\mathrm{Ca}^{2+}$ current activated by depletion of intracellular $\mathrm{Ca}^{2+}$ stores in human macrophages. Journal of Membrane Biology, 146: 101-111.

37. Nelson DJ, Jow B \& Jow F (1990). Wholecell currents in macrophages: I. Human monocyte-derived macrophages. Journal of Membrane Biology, 117: 29-44.

38. Fairley-Grenot KA \& Assmann SM (1992) Permeation of $\mathrm{Ca}^{2+}$ through $\mathrm{K}^{+}$channels in the plasma membrane of Vicia faba guard cells. Journal of Membrane Biology, 128: 103-113.

39. Marty A (1983). Blocking of large unitary calcium-dependent potassium currents by internal sodium ions. Pflügers Archives, 396: 179-181.

40. Randriamampita C, Bismuth G \& Trautmann A (1991). $\mathrm{Ca}^{2+}$-induced $\mathrm{Ca}^{2+}$ release amplifies the $\mathrm{Ca}^{2+}$ response elicited by inositol triphosphate in macrophages. Cell Regulation, 2: 513-522.

41. Tepikin AV \& Petersen OH (1992). Mechanisms of cellular calcium oscillations in secretory cells. Biochimica et Biophysica Acta, 1137: 197-207.

42. Bezprozvanny I, Watras J \& Ehrijch BE (1991). Bell-shaped calcium response curves in Ins(1,4,5)P3- and calcium-gated channels from endoplasmic reticulum of cerebellum. Nature, 351: 751-754. 